\title{
RUSSIA'S BALANCE OF PAYMENTS IN JANUARY-SEPTEMBER ${ }^{1}$ A.Bozhechkova, P.Trunin, M.Khromov
}

Russia's current account surplus was affected considerably by falling exports, whereas imports declined at a slower rate, as compared with the same period previous year. In January-September 2016, net capital outflow in the private sector is reported to be five times less than what it was during the same period previous year, as the rate of repayment of bank debts and liabilities slowed down, as a result of which the rouble appreciated in real terms in JanuarySeptember 2016 to the level seen early in 2006.

According to the Bank of Russia's preliminary assessment of the balance of payments (BoP) for January-September 2016, the current account balance stood positive at $\$ 15.6 \mathrm{bn}, 71.3 \%$ ( $\$ 54.4 \mathrm{bn})$ below the value seen JanuarySeptember 2015. Such a considerable contraction resulted from a decline in the trade balance, as the decline in exports was faster than the contraction of imports of goods and services.

\section{Balances}

In January-September 2016, exports of goods contracted by $23.6 \%$ from what it was in the same period previous year (from $\$ 260.4 \mathrm{bn}$ to $\$ 199.0 \mathrm{bn}$ ), including exports of crude oil (down $24.3 \%$ to $\$ 52.7 \mathrm{bn}$ ) and natural gas (down $31.6 \%$ to $\$ 21.4 \mathrm{bn}$ ), due to low global prices of energy-carrying resources. Indeed, in January-September 2016, the Brent crude was traded by an average of $24.5 \%$ below the price set in the same period previous year, while imports of goods dropped as little as $4.4 \%$ (from $\$ 142.1 \mathrm{bn}$ to $\$ 135.9 \mathrm{bn}$ ) below the figure recorded in January-September 2015, which was driven by a stronger rouble (up $9.7 \%$ in real terms by December 2015) and slower decline in aggregate demand (in January-August 2016, decline rates of real wages slowed down to $0.4 \%$ against the fall of $8.7 \%$ in the same period of 2015), as a result of which a positive trade balance contracted by $46.6 \%$ (from $\$ 118.2$ bn to $\$ 63.1 \mathrm{bn}$ ) (Fig. 1).

The decline (in absolute terms) in a negative service balance, compensation of employees balance and investment income balance prevented the current account balance from contracting further in January-September 2016. Indeed, a service balance deficit stood at $\$ 18.2 \mathrm{bn}$ in January-September 2016 , which is $39.3 \%$ (in absolute terms) below the value recorded in January-September 2015: imports of services dropped $19.4 \%$ to $\$ 57.8 \mathrm{bn}$ largely because individuals continued to cut back on their international travel expenses, while exports of services fell $3.7 \%$ to $\$ 36.6 \mathrm{bn}$.

The compensation of employees balance increased (in absolute terms) $65.9 \%$ to $\$ 4.1 \mathrm{bn}$ ( $\$ 1.4 \mathrm{bn}$ in January-September 2015). An investment income balance deficit was down 9.3\% (from \$25.7bn to \$23.3bn) from the value recorded in the same period previous year due to lower costs of ser-

1 This paper was originally published in Online Monitoring of Russia's Economic Outlook No.16(34). 


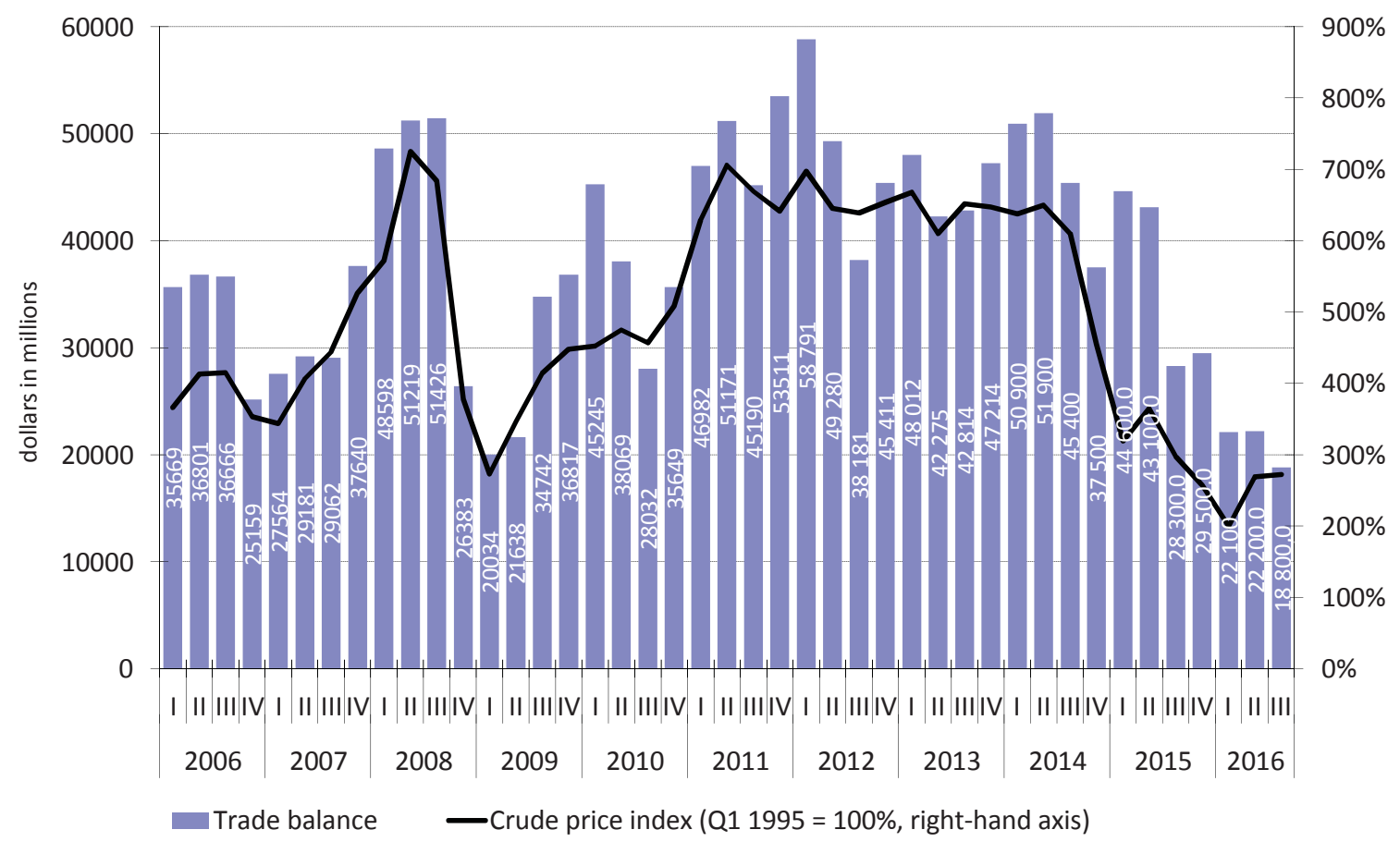

Sources: Bank of Russia, Gaidar Institute's own research.

Fig. 1. Russia Trade Balance and global oil price index in 2006-2016

vicing foreign debts and liabilities that were reduced. Investment income receivable dropped $8.0 \%$ (from $\$ 25.1 \mathrm{bn}$ to $\$ 23.1 \mathrm{bn}$ ) due to contraction of foreign asset holdings in the private sector. The income payable at nonfinancial enterprises decreased by $10.9 \%$ ( $\$ 38.4 \mathrm{bn})$. The income receivable in the banking sector increased from $\$ 7.1 \mathrm{bn}$ in January-September 2015 to $\$ 8.1 \mathrm{bn}$ in January-September 2016, which resulted in an overall positive investment income balance of $\$ 1.7 \mathrm{bn}$ (it was negative ( $\$ 0.9 \mathrm{bn}$ ) in JanuarySeptember 2015).

\section{Capital outflow dynamics}

The decline in a current account surplus was attended by a comparable contraction of the financial account deficit of $\$ 6.6 \mathrm{bn}$ in January-September 2016 (against $\$ 59.5 \mathrm{bn}$ in January-September 2015). The non-public sector saw net capital outflow amount to \$9.6bn in Q1-Q3 2016, including \$2.5bn in Q3. In absolute terms, the outflow in M9 2016 was found to be five times less than the outflow $(\$ 48.1 \mathrm{bn})$ seen in the same period of 2015 , although net capital inflow amounted to $\$ 3.4 \mathrm{bn}$ in Q3 2015, in contrast to 2016, when the balance of non-public sector capital operations with the rest of the world was found to be positive (\$0.9bn) in Q2 (Fig. 2).

The observed capital outflow dynamics can almost fully be explained by banking sector operations. The balance of Russian bank capital operations with the rest of the world increased \$41.3bn in Q1-Q3 2016 over the same period previous year, as a result of which the 2015 net outflow of $\$ 37.7 \mathrm{bn}$ gave way to the inflow of $\$ 3.6 \mathrm{bn}$ in 2016.

It is the slower rate of repayment of bank debts and liabilities that had the biggest effect on the dynamics of the balance of bank operations with the rest of the world. Bank debts and liabilities to non-residents were reduced by $\$ 19.7 b n$ in Q1-Q3 2016, whereas they decreased by $\$ 50.6 b n$ in the pre- 


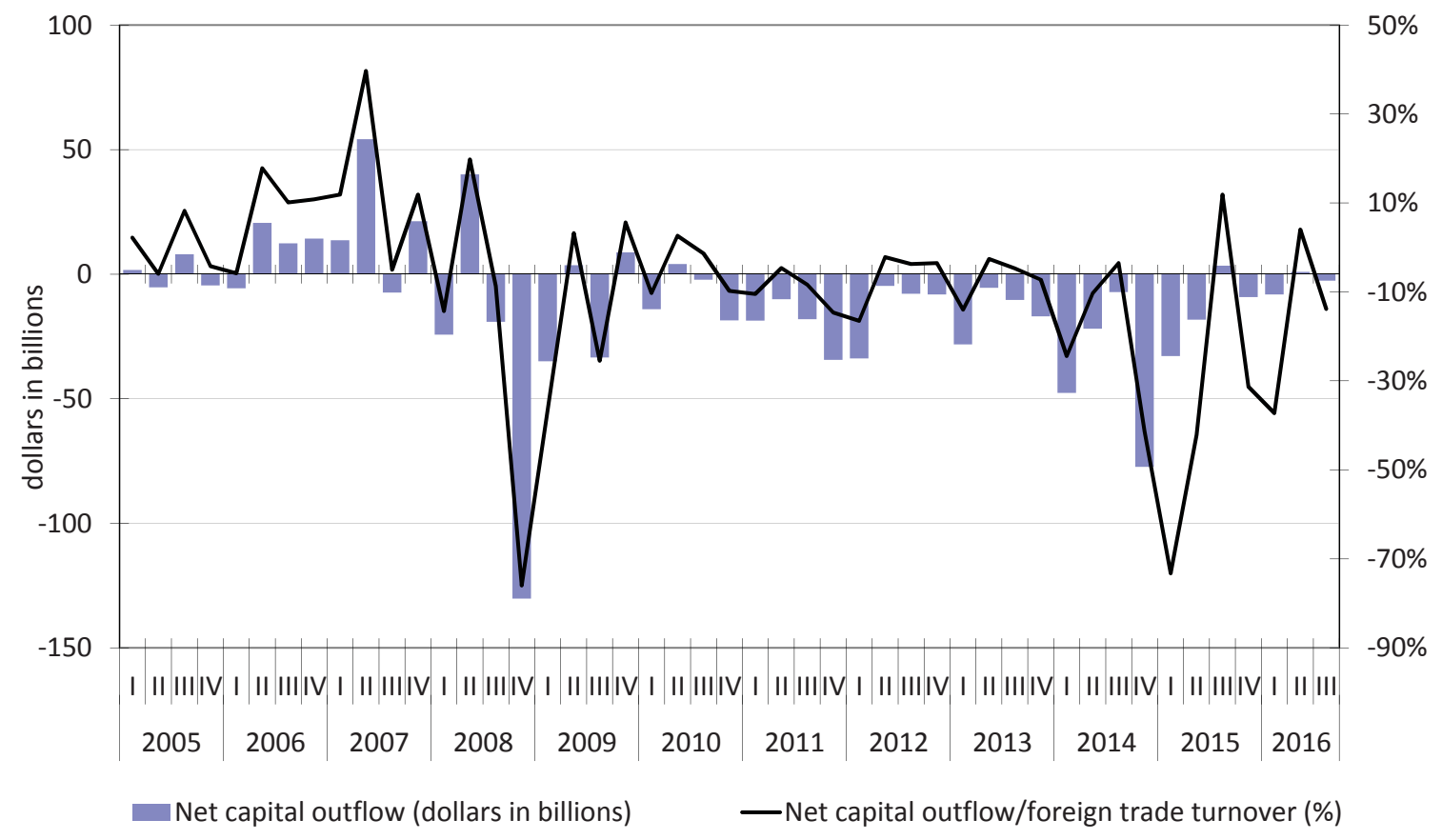

Sources: Bank of Russia, Gaidar Institute's own research.

Fig. 2. Net capital outflow in private sector

vious year. Bank payments due under the foreign debt repayment schedule were reduced insignificantly (from \$29.7bn in Q1-Q3 2015 to \$23.1bn in the same period of 2016). At the same time, no reduction whatsoever was seen in bank debts and liabilities to non-residents (in Q1-Q3 2015, earlier (than scheduled) repayments contracted by $\$ 20.9 \mathrm{bn})$. Furthermore, reduction of bank foreign debts and liabilities in Q1-Q3 2016 was found to be less (by $\$ 3.4 \mathrm{bn}$ ) than scheduled, which is an indication of partial refinancing or new fundraising.

Besides slower reduction of foreign debts and liabilities, banks hastened to reduce their foreign asset holdings in Q1-Q3 2016. While they were reduced by $\$ 12.9$ bn in Q1-Q3 2015, the reduction in the same period of 2016 was $\$ 23.3 \mathrm{bn}$. This dynamics can in part be explained by bank repayment of repos with the Bank of Russia. Bank foreign currency debts and liabilities to the central bank were reduced by \$12.3bn in M9 2016.

Net capital outflow from other sectors increased \$2.7bn in Q1-Q3 2016, as compared to the same period previous year. The increase (by $\$ 6.6 \mathrm{bn}$ ) in non-bank sector foreign debts and liabilities almost equals the level $(\$ 6.0 \mathrm{bn})$ recorded in the same period of 2015 . At the same time, the inflow pattern of non-bank sector foreign debts and liabilities underwent some changes: direct investment inflow increased \$6bn (from \$2.3bn in Q1Q3 2015 to $\$ 8.3 \mathrm{bn}$ in Q1-Q3 2016) while other fundraising decreased by \$5.4bn: the inflow of \$3.7bn in Q1-Q3 2015 gave way to the outflow of $\$ 1.7 \mathrm{bn}$ in the same period of 2016 . The reduction in the inflow of other debts and liabilities was attended by the reduction of payments (from $\$ 64.3 \mathrm{bn}$ in Q1-Q3 2015 to $\$ 52.7 \mathrm{bn}$ in Q1-Q3 2016) due under the foreign debt repayment schedule. However, non-bank borrowers managed to obtain as little as $\$ 51.1 \mathrm{bn}$ of new foreign loans in 2016 , whereas they raised $\$ 68.0 \mathrm{bn}$ a year earlier. 


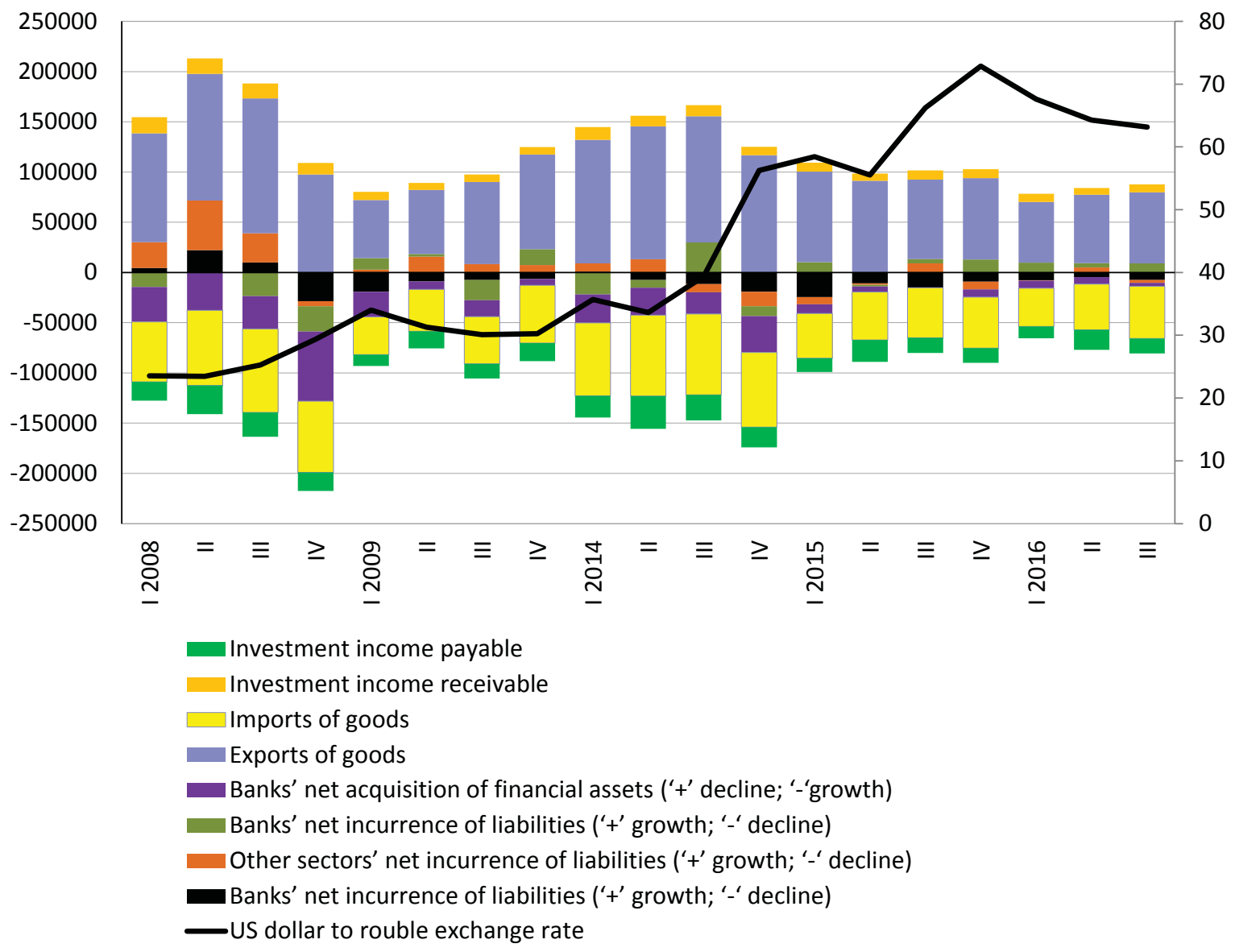

Source: Russia's central bank.

Fig. 3. Key sources of foreign currency supply and demand

Note that the process of individuals investing in foreign currency cash stopped in foreign asset operations in other sectors. Our estimates show that in Q1-Q3 2016 the balance of foreign currency in cash held outside the Russian banking sector increased $\$ 1.2 \mathrm{bn}$, whereas it decreased by $\$ 10.6 \mathrm{bn}$ in the same period of 2015.

The BoP data show that international reserve assets increased $\$ 10.1 \mathrm{bn}$ in January-September 2016 because the banking sector met outstanding foreign currency obligations to the central bank.

Thus, a positive trade balance in January-September 2016 contributed to a considerably smaller foreign currency inflow to the country, as compared to the same period previous year, because exports of goods were declining at a higher rate than imports. However, the downward pressure upon the rouble due to the decline in a positive trade balance in $\mathrm{H} 12016$ was offset by across-the-board cutbacks in capital outflow, especially in the banking sector (Fig. 3).

\section{Rouble exchange rate}

In January-September 2016, the US dollar to rouble nominal exchange rate decreased by $13.3 \%$ from 72.9 to 63.2 roubles per US dollar due to the above-noted trends in the dynamics of various components of the balance of payments and because prices of energy-carrying resources increased in Q2-Q3 from Q1 and capital outflow slowed down. As a reminder, the US dol- 
lar was traded at more than 80 roubles in the foreign exchange market in the second half of January 2016. In January-September 2016, with a stable inflation rate and a strengthening (in nominal terms) rouble, the rouble real effective exchange rate increased 9.6\% from what it was in December 2015, reaching the level recorded earlier in 2006.

Despite the rouble appreciation in January-September 2016, there is high risk that the rouble will depreciate in the mid-term because crude prices may fall due to a disproportionality between supply and demand in the global market. This may be worsened by a slowdown in the China economic growth, as well as by a tighter Fed's monetary policy, thus making US assets relatively more attractive, which results in capital outflows from other developed and emerging markets, including Russia. 